\title{
DEFERENCE TO FEDERAL CIRCUIT COURT INTERPRETATIONS OF UNSETTLED STATE LAW: FACTORS, ETC, INC. v. PRO ARTS, INC.
}

Federal courts have long been presented with cases in which they must ascertain and apply state law. This situation most often arises when the courts exercise diversity jurisdiction to adjudicate legal disputes between citizens of different states. ${ }^{1}$ Once a federal court determines that it must apply state law, it faces the problein of ascertaining what that law is. In the landmark decision Erie Railroad Co. v. Tompkins, ${ }^{2}$ the United States Supreme Court held that federal courts sitting in diversity inust apply state law as "declared by [the state's] Legislature in a statute or by its highest court. . ...3 Thus, although the Erie case established clear guidelines for federal court ascertainment of state law already determined by statute or by a decision of the state's supreme court, it did not instruct federal courts how to decide questions of state law that had not yet been decided authoritatively. ${ }^{4}$

1. Congress bestowed diversity jurisdiction on the federal courts by the Judiciary Act of 1789, \& 11, 1 Stat. 78 (1789). This jurisdiction is currently limited by the requirement that the amount in controversy be at least $\$ 10,000.28$ U.S.C. $\$ 1332$ (1976).

The traditional explanation for diversity jurisdiction is the concern that nonresidents would be subject to the bias of local tribunals. See C. WRIGHT, FEDERAL CourTs \& 23, at 85 (3d ed. 1976) (citing Bank of the United States v. Deveaux, 5 U.S. (1 Cranch) 61, 87 (1809) (Marshall, C.J.)). This explanation has been disputed, particularly by those who favor the abolition of diversity jurisdiction. See, eg., Friendly, The Historic Basis of Diversity Jurisdiction, 41 HaRv.'L. Rev. 483 (1928). But see Frank, Historical Bases of the Federal Judicial System, 13 LAw \& CONTEMP. ProBs. 1, 27-28 (1948) (concluding that the possibility of local prejudice cannot be ruled out). For a general discussion of the merits of diversity jurisdiction, see C. WRIGHT, supra, $\S 23$, at $88-92$.

2. 304 U.S. 64 (1938).

3. Id. at 78. Erie ushered out the doctrine of Swift v. Tyson, 41 U.S. (16 Pet.) 1 (1842), under which courts had labored for over ninety years. The Swift doctrine had established a nebulous dichotomy between matters of "general" law, which the federal courts could find for themselves, and matters of "local" law, in which federal courts were to defer to state decisions. At the time of the Erie decision, the doctrine of Swift $v$. Tyson had been increasingly under attack. The independent determination by the federal courts of questions of general law had not produced the desired uniformity in the law, but had instead enabled many hitigants to circumvent state law by forum-shopping. See C. WRIGHT, supra note 1, § 54, at 251-52.

4. It is not surprising that the Supreme Court did not address this issue, because the question before the Court in Erie was not what the state law was but rather whether state law governed at all. The Court remanded the case to the Court of Appeals for the Second Circuit for a determination of the state law question. 304 U.S. 64, 80 (1938). 
The process by which federal courts are to ascertain unsettled state law has remained largely ill-defined since Erie. Until recently, this issue arose inost frequently in cases in which federal courts were forced to decide the degree of deference to be afforded to prior interpretations of state law by intermediate state courts. In addressing this issue, the United States Supreine Court has gradually moved from requiring federal courts to follow virtually all state law decisions by state courts 5 toward a more flexible approach that allows federal courts greater scope to interpret unsettled state law. ${ }^{6}$

In the recent case of Factors, Etc., Inc. v. Pro Arts, Inc., ${ }^{7}$ the Umited States Court of Appeals for the Second Circuit revived the former, highly deferential approach in a different context. It held that a federal court of appeals' interpretation of the law of a state located within its circuit is binding, in the absence of an authoritative state declaration to the contrary, on federal courts in other circuits. ${ }^{8}$ This note focuses on the reappearance of the immediate post-Erie standard of deference in Factors, and argues that the Factors court pursued the goal of uniformity in the application of state law among the federal courts of appeals at the expense of the inore important Erie aim that a federal court ascertain state law in the same manner as would a court of that state. ${ }^{9}$ The note suggests that by emphasizing intercircuit uniformity rather than federal-state court uniformity, the Factors holding circumvents the broader purposes of the Erie doctrine-the deterrence of forum-shopping and the equitable administration of the law. ${ }^{10}$ The note concludes that the Factors standard of deference is too rigid and too arbitrary to be workable, ${ }^{11}$ and proposes a more flexible approach to intercircuit deference that would better promote the equitable and orderly developinent of state law. ${ }^{12}$

\section{Federal Court Ascertainment of Unsettled State Law}

\section{A. Fidehity Union Trust v. Field's Strict Standard of Deference}

The Suprene Court's decisions in Fidelity Union Trust Co. $v$. Field ${ }^{13}$ and three other cases ${ }^{14}$ during the 1940 term signaled the end

5. See infra notes 13-29 and accompanying text.

6. See infra notes $30-42$ and accompanying text.

7. 652 F.2d 278 (2d Cir. 1981), cert. denied, 102 S.Ct. 1973 (1982), judgment stayed, 541 F. Supp. 231 (S.D.N.Y. 1982).

8. For a detailed discussion of the Factors holding, see infra text accompanying notes 53-76.

9. See infra notes $83-85$ and accompanying text.

10. See infra notes $86-93$ and accompanying text.

11. See infra notes 101-09 and accompanying text.

12. See infra notes $117-34$ and accompanying text.

13. 311 U.S. 169 (1940).

14. Six Cos. v. Joimt Highway Dist. No. 13, 311 U.S. 180 (1940); West v. American Tel. \& Tel. Co., 311 U.S. 223 (1940); Stoner v. New York Life Ins. Co, 311 U.S. 464 (1940). 
of a short post-Erie period during which federal courts exercising diversity jurisdiction had continued to apply general common law in the absence of a controlling state statute or state supreme court decision. ${ }^{15}$ In Field the Supreme Court held that the Court of Appeals for the Third Circuit was bound to follow two New Jersey Court of Chancery decisions that clearly contradicted the language of a state statute. ${ }^{16}$ The Court stated that the chancery court had declared and apphed state law as an "organ of the State,"17 and that in the absence of "more convincing evidence," the federal courts should follow its determination. ${ }^{18}$

The Court based its policy of strict deference primarily on the assumption that it would lead to a more uniforn apphication of state law in the state and federal courts. ${ }^{19}$ Chief Justice Hughes expressed this desire for uniformity im his Field opinion as follows: "It is madmissible that there should be one rule of state law for litigants in the state courts and another rule for litigants who bring the same question before the federal courts owing to the circuinstances of diversity of citizenship."20 When apphed im practice, however, the Field court's policy of strict deference failed to achieve this goal; instead, it produced a number of adverse results. First, by insisting that federal judges follow all state court decisions im near mechanical fashion, the Court effectively substi-

15. See, e.g., Six Cos. v. Joint Highway Dist. No. 13, 110 F.2d 620, 626 (9th Cir.), rev'd, 311 U.S. 180 (1940); New York Life Ins. Co. v. Stoner, 109 F.2d 874, 878 (8th Cir.), rev'd, 311 U.S. 464 (1940); Field v. Fidelity Union Trust Co., 108 F.2d 521, 526 (3d Cir. 1939), rev'd, 311 U.S. 169 (1940); West v. American Tel. \& Tel. Co., 108 F.2d 347, 350 (6th Cir. 1939), rev'd, 311 U.S. 223 (1940).

16. The Field case concerned the validity under New Jersey law of "Totten trusts." Prior to 1932 such trusts were invalid, but in 1935 the state passed four statutes permitting then. Two vice-chancellors rionetheless declared the trusts invalid. The Third Circuit then applied the statutes, and concluded that the chancery court decisions did not express the state law. Ironically, New Jersey courts later chose to follow the Third Circuit holding rather than the chancery court decisions upheld by the Supreme Court. See Kurland, Mr. Justice Frankfurter, The Supreme Court and the Erie Doctrine in Diversity Cases, 67 YALE L.J. 187, 207 n.97 (1957).

17. 311 U.S. at 177. The New Jersey Court of Clancery was a court of original and statewide jurisdiction. The vice-chancellors' decisions, lowever, would not lave been binding on other vice-chancellors or on the state's highest court. C. WRIGHT, supra note $1, \S 48$, at 267.

18. 311 U.S. at 178. Although the Court did not explain what it meant by "more convincing evidence," the opinion indicated that there was a strong presumption that the cliancery court had interpreted state law correctly and that the Third Circuit was not free to reverse the state court holding merely because it disagreed. Id.

19. It has been suggested that the Supreme Court's desire to curb the independence of federal judges who had been openly hostile toward Erie also may have contributed to the highly deferential approach set forth in Field. See Note, The Ascertainment of State Law in a Federal Diversity Case, 40 IND. L.J. 541,548 (1965).

20. 311 U.S. at 180. 
tuted one kind of forum-shopping for another. ${ }^{21}$ Under the Field rule, individuals seeking to have existing state law applied would choose to litigate in a federal forum because the federal courts could not diverge from existing law. By contrast, individuals seeking a change in the law would choose to litigate in a state court because only that tribunal would be free to consider the issue fully and to hold contrary to estabhished law.22

A second adverse consequence of the Field policy was its constriction of the role of federal judges in cases involving unsettled questions of state law. Lower federal courts responded to Field and its companion cases by showing unwavering deference to virtually all intermediate state court holdings, ${ }^{23}$ including decisions that had no precedential value within a state's court systen. ${ }^{24}$ The prospect of being reversed on appeal for not considering even the nost tangential state court authority prompted some federal courts to search extensively for state court dicta before turning to their own reasoning or to sources outside state law. ${ }^{25}$ One federal court declined jurisdiction completely when it could not readily ascertaim from state law how a state court would have de-

21. See C. WRIGHT, supra note $1, \S 58$, at 270 ; Kurland, supra note 16 , at 212 . Under the previous type of forum-shopping, litigants had sought the federal forum to obtain an application different from that which a state court would apply. In contrast, forum-shoppers under Field sought the federal forum because it would apply existing state law more predictably than the state courts themselves. Professor Moore commented on this phenomenon: "Blind adherence would . . . give state court decisions which have the effect of stare decisis in state courts, the strength of res judicata in federal courts." 1A J. MOORE, Federal PRACTICE [ 0.309[1], at 3113 (2d ed. 1981).

22. See Kurland, supra note 16, at 212.

23. See, e.g., Gettins v. United States Life Ins. Co., 221 F.2d 782, 785 (6th Cir. 1955). The court in Gettins leld that it was bound by an intermediate state court decision in the absence of a contrary holding by the Ohio Supreme Court and declined "to exercise [its] independent judgment, to look to other jurisdictions, or to speculate as to what the Supreme Court of Ohio might some day decide." Id.; see also McLouth Steel Corp. v. Mesta Mach. Co., 214 F.2d 608, 610 (3d Cir. 1954) (court could not hold contrary to intermediate state court decision, even when it thought highest state court would later overrule that decision).

24. See West v. American Tel. \& Tel. Co., 311 U.S. 223 (1940). In West the Supreme Court held that a decision of an Ohio county court of appeals was binding on a federal court, even though the county court of appeals' decisions had little or no weight as precedent in other Ohio state courts. Id. at 237.

25. One commentator sharply criticized the practice of regarding dicta from state court decisions as binding, and described this development as substituting "stare dictis" for stare decisis. See Boner, Erie v. Tompkins: A Study in Judicial Precedent II, 40 Tex. L. Rev. 619, 622-23 (1962), (quoting Oliphant, A Return to Stare Decisis, 14 A.B.A. J. 71, 72 (1928) (coining the phrase "stare decisis")).

Former Chief Judge Parker of the Fourth Circuit, referring to this expansion of the Erie doctrine, condemned decisions that relied on "tortuous reasoning from dicta or cases not in point ... to support propositions that the courts of the state have never decided and no court in any state is ever likely to decide." Parker, Erie v. Tompkins in Retrospect: An Analysis of Its Proper Area and Limits, 35 A.B.A. J. 19, 83 (1949). 
cided a complex question of state law, ${ }^{26}$ only to have the Supreme Court reverse its decision to abstain. ${ }^{27}$

The Field pohcy of deference engendered bitter opposition from federal judges who felt they were being forced to "abdicate [their] judicial functions." 28 Some commentators charged that by stripping federal judges of their authority to evaluate precedent im the same manner as state judges, the Field rule was actually depriving diversity hitigants of their basic right to a fair trial. ${ }^{29}$

26. Meredith v. City of Winter Haven, 134 F.2d 202 (5th Cir.), rev'd, 320 U.S. 228 (1943) (dismissing plaintiffs claim without prejudice to his right to proceed in state court to secure a determination on the question of enforceability of deferred-interest coupons attached to bonds).

27. Meredith v. City of Winter Haven, 320 U.S. 228 (1943). Declining to sanction the Fifth Circuit's abstention, the Court stated that "Erie R.R. Co. v. Tompkins . . . did not free the federal courts from deciding questions of state law in diversity cases." Id. at 237. The court concluded that "[i]n the absence of some recognized public policy, . . . denial of [the] opportunity [to litigate in a federal rather than a state forum] by the federal courts merely because the answers to the questions of state law are difficult or uncertain or have not yet been given by the highest court of the state, would thwart the purpose of the jurisdictional act." Id. at 234-35; see also Daily v. Parker, 152 F.2d 174 (7th Cir. 1945) (in absence of state court decision, duty of federal court was to decide, and not to avoid, the question). In light of the recent growth of the abstention doctrine, the Meredith holding may no longer represent an absolute rule. See C. WRIGHT, supra note 1, $\S 58$, at $270 \mathrm{n} .29$.

28. Clark, State Law in the Federal Courts: The Brooding Omnipresence of Erie v. Tompkins, 55 YALE L.J. 267, 290-91 (1946). .Judge Clark stated:

[T] he current view . . . is that we must act as a hollow sounding board, wooden mdeed, for any state judge who cares to express himself. . . . Why should we abdicate our judicial functions and even prostitute our intellectual capacities to discover not state law, but the particular views a state judge may liave uttered many years ago under different circumstances?

Id. See Richardson v. Commissioner, 126 F.2d 562, 567 (2d Cir. 1942) (Frank, J.) (federal judges are not to "play the role of ventriloquist's dummy to the courts of some particular state"); Friendly, In Praise of Erie-And of the New Federal Common Law, 39 N.Y.U. L. REv. 383, 40001 (1964) (referring to Field and its companion cases as "the excesses of 311 U.S."); see also Hart, The Relations Between State and Federal Law, 54 CoLum. L. Rev. 489, 510 (1954) ("second-rate justice" would result if federal courts were bound to adhere to intermediate state court decisions); Corbin, The Law of the Several States, 50 YALE L.J. 762, 768, 775 (1941) (A federal court "must use its judicial brains, not a pair of scissors and a paste pot.")

29. See Corbin, supra note 28 , at 775 . Professor Corbin asked:

Shall a litigant, by the accident of diversity of citizenship, be deprived of the advantages of this judicial process. . .? We innst not forget that a litigant lias only one day in court. When forced into a federal court, that is his ouly court. If he is denied life, liberty, or property by the narrow syllogistic nse of a state judge's worded doctrine, lee is not restored by the fact that intelligent state judges later refuse to apply that doctrine to other litigants. True, he has had his day in court; but what a court!

Id. See also Clark, supre note 28, at 291. Judge Clark restated Corbim's criticism of Field's rule of deference as follows: "[A]nything short of full judicial action on the part of the federal judges is a deprivation of the rights of the litigants to due process and a fair trial." Clark labeled Corbin's view "the best advice and exposition of the [Erie] doctrine possible," and noted that the federal courts" "attempted departures from that conduct are what have inade the Tompkins result seem at times bizarre and strange." Id. Framed in the context of Erie rather than due process, the Field rule of deference could be said to have deprived diversity litigants of the best rule of decision 


\section{B. Field's Strict Standard Relaxed}

In the decades following the Field decision, the Supreme Court showed signs of relaxing its requirement that federal courts defer to all lower state court interpretations of unclear state law. In King $\boldsymbol{v}$. Order of United Commercial Travelers of America, ${ }^{30}$ decided in 1948, the Court held that an unreported decision by a South Carolina court of common pleas was not binding on a federal court sitting in diversity. ${ }^{31}$ The Court reasoned that because the court of common pleas' decision was not binding on any state court within South Carolina, "it would be incongruous indeed to hold a federal court bound by [the] decision."32

In the 1956 case of Bernhardt v. Polygraphic Co. of America, ${ }^{33}$ the Supreme Court held that a 1910 Vermont state court decision was still binding on federal courts, but indicated in dictum the kind of evidence that might have permitted the federal court to disregard the state court decision:

[T]here appears to be no confusion in the Vermont decisions, no developing line of authorities that casts a shadow over the estabhshed ones, no dicta, doubts or ambiguities in the opinions of Vermont judges on the question, no legislative development that promises to undermine the judicial rule. ${ }^{34}$

In its 1967 decision in Commissioner v. Estate of Bosch, ${ }^{35}$ the Court appeared to abandon entirely the Field policy of strict deference, holdimg that an intermediate state court decision should be given "proper regard," but was not binding authority in a federal court. ${ }^{36}$

under the circumstances merely because the forum was federal. See Note, Unclear State Law in the Federal Courts: Appellate Deference or Review?, 48 MINN. L. REv. 747, 759 (1964).

30. 333 U.S. 153 (1948).

31. Id. at 162. The Court stated that, although the unreported decision was entitled to "some weight," it was not to be a "coutrolling factor" in a federal court's decision. Id.

32. Id. The Court noted that because the court of common pleas' decision did not require deference from other courts within the state, it did not fall within the West Court's definition of "'rules of decision commonly accepted and acted upon by the bar and inferior courts." Id. at 161 (footnote omitted) (citing West v. American Tel. \& Tel. Co., 311 U.S. 223, 236 (1940)). As an alternative ground for its decisiou, the Court cited the difficulty of obtaining the unreported decisions of the court of common pleas. 333 U.S. at 161-62.

33. 350 U.S. 198 (1956).

34. Id. at 205.

35. 387 U.S. 456 (1967). Bosch was not a diversity case, but involved the analogous issue of whether a federal court or agency was bound by an imtermediate state court's determination of the property rights of the parties in a federal estate tax case.

36. Id. at 465 . The Court stated:

Under some conditions, federal authority may not be bound even by an intermediate state appellate court ruling. . . . If there be no decision by [the state supreme] court then federal authorities must apply what they find to be the state law after giving "proper regard" to relevant rulings of other courts of the State. 
In light of the Supreme Court's decisions in King, Bernhardt, and Bosch, lower federal courts facing undecided questions of state law have increasingly looked beyond state court decisions to such sources as restatements of the laws, ${ }^{37}$ law review commentaries, ${ }^{38}$ relevant decisions by courts of other states and by federal courts, ${ }^{39}$ and to the general weight of authority. 40 In short, federal courts faced with questions of unsettled state law are now free to consider all data that a state court would use in deciding the issue..$^{41}$ Partly as a result of this mcreased freedom, however, a new version of an old question has emerged:42 what degree of deference should federal courts afford interpretations of state law by other federal courts?

\section{Deference Within the Federal Court System on Unsettled Questions of State Law}

The issue of federal court deference to state law interpretations by other federal courts arises inost often in the context of federal appellate review. The Supreme Court has on occasion deferred to a lower federal court's determination of an unsettled issue of state law.43. More frequently, federal courts of appeals afford deference on direct review

37. See, e.g., Tri-Tron Int'1 v. Velto, 525 F.2d 432, 436 (9th Cir. 1975) (in absence of Montana law on subject of trade secrets, district court properly turned to the Restatement of the Law of Torts); Patch v. Stanley Works, 448 F.2d 483, 488-89 (2d Cir. 1971); Gates v. P.F. Collier, Inc., 378 F.2d 888, 892 (9th Cir. 1967), cert. denied, 389 U.S. 1038 (1968); Glassman Constr. Co. v. Fidelity \& Cas. Co., 356 F.2d 340, 342 n.3 (D.C. Cir.), cert. denied, 384 U.S. 987 (1966).

38. See Wendt v. Lillo, 182 F. Supp. 56,60 (N.D. Iowa 1960); see also J. MOORE, supra note 21, I 0.309 [2], at $3124 \mathrm{n} .21$.

39. See, eg., Gray v. Travelers Indem. Co., 280 F.2d 549, 554 n.2 (9th Cir. 1960) (court would look to conflicts law of Alaska in absence of determination by Washington courts); Yost $v$. Morrow, 262 F.2d 826, 828 n.3 (9th Cir. 1959) (on unclear questions of Idaho law, court looked to decisions of Idaho's sister state, Oregon); Wilmington Trust Co. v. Mutual Life Ins. Co., 76 F. Supp. 560, 564 (D. Del. 1948) (court took legal notice that Delaware courts pay particular attention to the courts of Massachusetts and New York). See also J. MoorE, supra note 21, \0.309 [2], at $3123 \mathrm{n} .19$.

40. See C. WRIGHT, supra note $1, \S 59$, at 271.

41. See id. \& 58, at 269 ("The federal judge need no longer be a ventriloquist's dummy. . ."). See also Friendly, supra note 28, at 401; Vestal, Erie R.R. V. Tompkins: A Projection, 48 lowa L. REv. 248, 256 (1963).

42. If federal courts conld still consider only state court decisions in deciding questions of state law, the question whether deference inust be given to the state law.rulings of other federal courts would rarely arise.

43. In MacGregor v. State Mut. Life Assurance Co., 315 U.S. 280 (1942), the Supreme Court held that in the absence of any relevant state court decisions on an issue of Michigan law, it would "leave undisturbed the imterpretation placed upon purely local law by a Michigan federal judge of long experience and of three circuit judges whose circuit includes Michigan." Id. at 281. See also Bermhardt v. Polygraphic Co., 350 U.S. 198, 204 (1956) (giving special weight to statement by federal district judge froin Vermont identifying Vermont law); Huddleston v. Dwyer, 322 U.S. 232, 237 (1944). 
to interpretations of state law by federal district judges. ${ }^{44}$ The rationale behind such deference is that a district court judge, who sits in a particular state and has practiced before that state's courts, can better decide questions of unsettled state law than a circuit court judge, who frequently lacks such experience. ${ }^{45}$

Federal courts of appeals have adopted different standards of deference in reviewing district court interpretations of state law on appeal. Many courts afford "great weight" or "considerable weight"46 to such decisions. Other courts consider themselves bound by district court interpretations of state law unless they are "clearly erroneous." 47 As a rule, deference has been limited to situations involving direct appellate review. Federal courts of appeals generally have not afforded deference to decisions by federal courts in other circuits, ${ }^{48}$ except in a few

44. See infra notes $46-47$.

45. See C. WRIGHT, supra note $1, \S 59$, at 271.

As a general proposition, a federal court judge who sits in a particular state and has practiced before its courts may be better able to resolve complex questions about the law of that state than is some other federal judge who has no such personal acquaintance with the law of the state. For this reason federal appellate courts have frequently voiced reluctance to substitute their own view of the state law for that of the federal judge. As a matter of judicial administration, this seems defensible.

Id.

46. See, e.g., Lamb v. Amalganated Labor Life Ins. Co., 602 F.2d 155, 160 (8th Cir. 1979) (court gave great weight to conclusion of federal district court judge on questions of state law, and was not able to say he had erred); Green v. American Broadcasting Cos., 572 F.2d 628, 632 (8th Cir. 1978); Randolph v. New England Mut. Life Ins. Co., 526 F.2d 1383, 1385 (6th Cir. 1975); Insurance Co. of N. Am. v. English, 395 F.2d 854, 860 (5th Cir. 1968). Contra Peterson v. U-Haul Co., 409 F.2d 1174, 1177 (8th Cir. 1969) (federal court decisions in diversity cases have no precedential value as state law and only determime the issues between the parties).

47. See, e.g., Gaines v. Haughton, 645 F.2d 761, 770 (9th Cir. 1981), cert. denied, 102 S.Ct. 1006 (1982); Smith v. Sturm, Ruger \& Co., 524 F.2d 776, 778 (9th Cir. 1975); Sade v. Northern Natural Gas Co., 501 F.2d 1003, 1006 (10th Cir. 1974); Julander v. Ford Motor Co., 488 F.2d 839, 844 (10th Cir. 1973); Binkley v. Manufacturers Life Ins. Co., 471 F.2d 889, 891 (10th Cir.), cert. denied, 414 U.S. 877 (1973). Professor Moore argues that the "clearly erroneous" standard of review is itself erroneous when apphed to questions of law, rather than findings of fact. See J. MOORE, supra note 21, 10 0.309[2], at 3128 n.28. Professor Wright agrees: "It would seem that a party is entitled to review of the trial court's determination of state law just as he is of any other legal question in the case, and that the decision of a local trial judge cannot reasonably be regarded as conclusive." C. WRIGHT, supra note 1, § 59, at 271.

The distinction between the "great weight" and "clearly erroneous" standards is not always clear, particularly because some courts use the term "great weight" while apparently applying a "clearly erroneous" standard. See, e.g., Scandinavian Airlines v. United Aircraft, 601 F.2d 425, 427 (9th Cir. 1979) ("The analysis by the district judge of the law of the state in which he sits is entitled to great weight and his determination will be accepted on review, unless shown to be clearly wroug.").

48. See Umited States v. Dawson, 576 F.2d 656, 659 (5th Cir.), cert. denied, 439 U.S. 1127 (1978) (Fifth Circuit in no way bound by decisions of other circuits); S.E.C. v. Shapiro, 494 F.2d 1301, 1306 n.2 (2d Cir. 1974); Coleman v. United States Dep't of Justice, 429 F. Supp. 411,413 (N.D. Ind. 1977); Ghandi v. Police Dep't, 74 F.R.D. 115, 122-23 (E.D. Mich. 1977). 
cases involving the specialized areas of taxation ${ }^{49}$ and administrative law. ${ }^{50}$ Until Factors, Etc., Inc. v. Pro Arts, Inc. ${ }^{51}$ no federal court of appeals had deferred to a prior determination of state law made by a federal court in another circuit. ${ }^{52}$

The Court of Appeals for the Eighth Circuit has occasionally departed from the general practice of affording no deference among the circuits by deferring to decisions by other courts of appeals when such decisions are not clearly wrong. The rationale behind this deference is one of maintaining uniformity of national law. The Eighth Circuit has stated:

Although we are not bound by another circuit's decision, we adhere to the policy that a sister circuit's reasoned decision deserves great weight and precedential value. As an appellate court, we strive to maintain uniformity in the law among the circuits, wherever reasoned analysis will allow, thus avoiding unnecessary burdens on the Supreme Court docket. Unless our 11 courts of appeals are thus willing to promote a cohesive network of national law, needless division and confusion will encourage further splimtering and the formation of otherwise unnecessary additional tiers in the framework of our national court system.

Aldens, Inc. v. Miller, 610 F.2d 538, 541 (8th Cir. 1979), cert. denied, 446 U.S. 919 (1980) (deferring to decisions in the Third, Seventh, and Tenth Circuits on constitutionahity of state consumer credit code provisions governing maximum finance charges); see also National Indep. Meat Packers Ass'n v. EPA, 566 F.2d 41, 43 (8th Cir. 1977); Estate of Spicknell v. Commissioner, 285 F.2d 561, 567 (8th Cir. 1961); Homan v. United States, 279 F.2d 767, 773 (8th Cir.), cerl. denied, 364 U.S. 866 (1960). The Eighth Circuit's rationale for deference seems to be totally separate froin the considerations of state law expertise identified by Professor Wright, for the Eighth Circuit has applied the rule of deference to decisions on state law interpretations by district court judges who were from another state and who thus possessed no particular knowledge of the state law adjudicated. See, e.g., St. Paul Hosp. \& Casualty Co. v. Helsby, 304 F.2d 758, 759 (8th Cir. 1962); Luther v. Maple, 250 F.2d 916, 922 (8th Cir. 1958).

49. Some federal courts of appeals have deferred to decisions by other circuits on tax matters in order to encourage uniformity in the tax laws. See, e.g., North Am. Life \& Casualty Co. v. Commissioner, 533 F.2d 1046, 1051 (8th Cir. 1976) (decisions of other courts of appeals im area of taxation should be followed, in interest of uniformity among circuits, unless they are demonstrably erroncous or there are cogent reasons for rejecting them); Federal Life Ins. Co. v. United States, 527 F.2d 1096, 1098-99 (7th Cir. 1975) (because respect for decisions of other circuits is especially important in promoting uniformity in tax cases, a decision of another circuit should be followed unless proved incorrect); $c f$. Gulf Inland Corp. v. Umited States, 570 F.2d 1277, 1278 (5th Cir. 1978) (courts of appeals may defer to each other in tax cases to promote uniformity, but stare decisis does not apply).

50. Some federal courts have given great weight to decisions on admimistrative law matters by the Court of Appeals for the District of Columbia Circuit because of that court's expertise in the administrative law area. See, e.g., City of Westfield v. Federal Power Comm'n, 551 F.2d 468 (1st Cir. 1977) (following holding of Court of Appeals for the District of Columbia Circuit that federal courts lack jurisdiction to review Federal Power Commission's orders, because views of that circuit carry great weight in administrative law matters). See also FTC v. Stanley H. Kaplan Educ. Center, 433 F. Supp. 989, 993 n.l (D. Mass. 1977) (views of the Court of Appeals for the District of Columbia Circuit carry great weight in administrative law matters).

51. 652 F.2d 278 (2d Cir. 1981), cert. denied, 102 S.Ct. 1973 (1982), judgment stayed, 541 F. Supp. 231 (S.D.N.Y. 1982).

52. In Maher v. Zapata Corp., 490 F. Supp. 348, 352 (S.D. Tex. 1980), a district court in the Fifth Circuit held that it was not bound by an Eighth Circuit decision concerning a matter of Delaware law because it was not convinced that the prior decision was supported by Delaware law. In Waters v. American Auto. Ins. Co., 363 F.2d 684, 689 (D.C. Cir. 1966), the Court of Appeals for the District of Columbia Circuit recognized that the Eighth Circuit's views on Missouri law were entitled to weight, but rather than defer to an Eighth Circuit decision interpretimg 


\section{FACTORS, ETC., INC. V. PRo ARTS, INC: A RetURn to A STRICT STANDARD OF DEFERENCE}

\section{A. The Reasoning of the Factors Court}

In Factors, Etc., Inc. v. Pro Arts, Inc., 53 a majority of the Court of Appeals for the Second Circuit held that in the absence of any definitive state court statement of Tennessee law, it was bound to defer to the decision of the Court of Appeals for the Sixth Circuit in Memphis Development v. Factors, Etc., Inc. ${ }^{54}$ that under Tennessee law $^{55}$ an individual's right of publicity is not descendible. ${ }^{56}$ Despite a strong

Missouri law, the court decided to follow a more recent state intermediate appellate court decision.

53. 652 F.2d 278 (2d Cir. 1981), cert. denied, 102 S.Ct. 1973 (1982), judgment stayed, 541 F. Supp. 231 (S.D.N.Y. 1982). Factors, Etc., Inc., a Delaware corporation, acquired an exclusive license to use the name and likeness of deceased singer Elvis Presley from Boxcar Enterprises, Inc., a corporation that Presley had formed and to which he had assigned exclusive ownership of his commercial rights. Id. at 279. When Pro Arts, Inc., an Ohio corporation, marketed a poster of Presley through various retail dealers, Factors brought suit in the District Court for the Southern District of New York and obtained a preliminary injunction restraining Pro Arts from making any commercial use of Presley's name or likeness. Factors, Etc., Inc. v. Pro Arts, Inc., 444 F. Supp. 288 (S.D.N.Y. 1977). The Court of Appeals for the Second Circuit affirmed the district court's issuance of the mjunction. 579 F.2d 215 (2d Cir. 1978), cert. denied, 440 U.S. 908 (1979). Factors subsequently moved for summary judgment in the case and the district court granted the motion, issuing a permanent injunction from which Pro Arts appealed. 496 F. Supp. 1090 (S.D.N.Y. 1980).

The Second Circuit reversed the district court's decision, deferring to the Sixth Circuit's prior determination that the right of publicity was not descendible under Tennessee law. See infra note 56. Pro Arts then moved for summary judgment in the district court based on the Second Circuit's decision. Factors moved for cross-summary judgment, or alternatively, a stay of entry of judgment. Factors cited as support for its motion a Tennessee clancery court decision rendered subsequent to Factors that held that the right of publicity was descendible under Tennessee law. See Commerce Union Bank v. Coors, 7 Media L. Rep. (BNA) 2204 (Tenn. Cl. 1981). See infra note 125 for a detailed discussion of the chancery court lolding. On May 11, 1982, Federal District Judge Tenney, whose original decision in the case was reversed by the Second Circuit in Factors, granted Factors' request to stay entry of judgment, allowing Factors to petition the Second Circuit for rehearing in light of Commerce Union Bank. See 541 F. Supp. 231 (S.D.N.Y. 1982).

54. 616 F.2d 956 (6th Cir.), cert. denied, 449 U.S. 953 (1980). In Memphis Development, a Tennessee nonprofit corporation sought an injunction to keep Factors, Etc., Inc., from interfering with its fund-raising promotion of Elvis Presley statuettes. The district court decided in favor of the defendant, Factors, holding that Presley's right of publicity was descendible because, among other reasons, the Tennessee court would follow the najority rule. Memphis Dev. Found. v. Factors, Etc., Inc., 441 F. Supp. 1323 (W.D. Tenn. 1977). The Sixth Circuit reversed the judgment, however, basing its holding that the right of publicity is not inheritable on general cousiderations independent of state law. 616 F.2d at 960 .

55. Factors contended for the first time on appeal that New York law, rather than Tennessee law, was applicable. The court held that Tennessee law applied because Tennessee was the place of Presley's domicile, of Boxcar Enterprises' incorporation, and of the signing of the agreement between Boxcar and Factors. Moreover, the agreement specifically provided that it would be construed in light of Tennessee law. 652 F.2d at 281.

56. 652 F.2d at 283. The court stated that in view of its disposition of the appeal, it need not consider Pro Arts' contention that the Sixth Circuit's decision in Memphis Development collater- 
dissent, ${ }^{57}$ the majority in Factors set forth the broad new rule that a court of appeals' interpretation of the unsettled law of a state located within its circuit should be given conclusive deference by other federal courts. ${ }^{58}$

The Factors court based its unprecedented holding of deference to the Sixth Circuit's decision partly on what it termed the "functioning of diversity jurisdiction."59 The court stated that the Sixth Circuit, "[i]n adjudicating a state-created right in the exercise of its diversity jurisdiction, ... . was 'for that purpose, in effect, only another court of the State." "60 Because the Sixth Circuit was "expounding upon Tennessee's version of the common law," 61 its decision should be regarded as binding although it was not based on Tennessee law62 or court methods $^{63}$ and was probably contrary to the result that the Second Circuit would have reached on the merits of the issue. ${ }^{64}$

ally estopped Factors from asserting a descendible right of publicity. Id. at 283 n.8. The dissent did address the collateral estoppel issue, however, concluding that given the circumstances of the case-most particularly the fact that the New York litigation was actually filed first-the policies behind the collateral estoppel rule would not be served by using Memphis Development as a bar. Id. at 289 (Mansfield, J., dissenting). But see Note, Federal Court's State Law Ruling Entitled to Conclusive Deference: Factors, Etc., Inc. v. Pro Arts, Inc., 1981 B.Y.U. L. Rev. 974, $980-82$ (rejecting the argument that collateral estoppel was inapphicable because action was filed first in New York on the ground that the district court's holding was not a final judgment, and concluding that the doctrine of collateral estoppel should have precluded consideration of the question of deference).

57. Judge Mansfield filed a dissenting opinion in which le took issue with the majority's reasoning, stating: "I see no warrant, if we disagree [with the Sixth Circuit] on the merits, for blindly following its decision in Memphis Development Foundation v. Factors, Etc., Inc., any more than we would defer to the decision of any other circuit court with which we might . . . disagree or conflict." 652 F.2d at 284 (Mansfield, J., dissenting).

58. The Factors court expressed its surprise that "no case appears to have turned on whether one court of appeals sliall defer to another circuit as to the law of the state within that circuit." 652 F.2d at 281 .

59. $652 \mathrm{~F} .2 \mathrm{~d}$ at 282 .

60. Id. at 282 (quoting Guaranty Trust Co. v. York, 326 U.S. 99, 108 (1945)). The Factors court looked to the York strain of Erie analysis to support its lolding. Under the "outcomedetermination" theory espoused by the Court in York, Erie requires the outcome of state law issues in federal diversity cases to be "substantially the same, so far as legal rules determine the outcome of litigation, as it [would] be if tried in the state court." 326 U.S. at 109. But see infra note 86 and accompanying text.

61. 652 F.2d at 281. The court stated that the Sixth Circuit in Memphis Development "had no power "to declare substantive rules of common law'; it could only declare the law of Teunessee." Id. at 282 (quoting Erie R.R. Co. v. Tompkins, 304 U.S. 64, 78 (1938)).

62. See infra note 73.

63. The dissenting judge in Factors, noting that the Sixth Circuit did not rely on "existent local law or methods," stated that the Memphis Development opinion "made no effort, as is sometimes done, to determine what other states the Tennessee courts tend to look to, much less to be guided by analogous primciples of Tennessee law." 652 F.2d at 285 (Mansfield, J., dissenting) (citations ounitted).

64. 652 F.2d at 282. Judge Newman, writing for the majority, stated that he "would probably uphold a descendible right of publicity, were he serving on the Tennessee Supreme Court, and perhaps if he served on the Sixth Circuit when Memphis Development was decided." It. The fact 
Underlying the Factors decision was the court's desire to bring about the uniform application of unsettled state law in the federal courts. The Factors court remarked that "sporadic federal court adjudications" in diversity cases had disrupted the "authoritative exposition of state law,"6s and stated that a policy of conclusive deference to interpretations of state law by "pertinent" courts of appeals" would enhance "both the orderly development of state law and fairness to those subject to state law requirements." 67 The court reasoned that a policy providing a simgle authoritative answer to previously unsettled questions of state law would promote "fairness to the public"68 and would better focus state legislative efforts on the appropriateness of statutory reform. ${ }^{69}$ The court also predicted that the uniforn application of state law in the federal courts would prompt other state courts to apply the federal rule because of a common interest in uniformity. ${ }^{70}$

The Factors court appeared anxious to bolster its holding with the argument that deference was warranted because the Sixth Circuit had a special knowledge of Tennessee law. Specifically, the majority stressed the status of the Second Circuit judges on the panel as "outsiders"71 with respect to Tennessee law, and noted that the author of the Sixth Circuit opinion was "a distinguished member of the Tennessee bar, whose sense of what may be expected of the Tennessee Supreme Court

that at least one of the judges in the inajority would have been inclined to decide the issue differently had the court not deferred to the Sixth Circuit decision is evidence of the unequivocal nature of the deference afforded in Factors. In contrast, most courts that have based their decisions on grounds of deference have also stated their agrcement with the merits of the previous decision, thus drawing into question the strength of the deference ground to such holdings.

65. 652 F.2d at 282 .

66. The majority employed the term "pertinent" to identify the particular court of appeals whose circuit's geographic boundaries encompass the state in question. Id.

67. 652 F.2d at 282 .

68. Id. The court rhetorically raised the following question: "If this Court were to disregard the Sixth Circuit's view and declare that Tennessee law recognizes a descendible right of publicity, what standard of conduct should guide Tennessee residents endeavoring to determine whether their publicity rights are to be valued ouly for a lifetime or beyond?" Id. at 283 .

69. Id at 282.

70. Id. \& n.6. For a critical discussion of these issues, see infra notes 95-99 and accompanying text.

71. The term "outsiders" with regard to state law was borrowed from the Supreme Court's opinion in Lehman Bros. v. Schein, 416 U.S. 386 (1974). In Lehman Brothers the Court reversed a decision by the Second Circuit on an unsettled question of Florida law and remanded the case to the district court for reconsideration of whether the issue should be certified to the Supreme Court of Florida. The Court stated that "[w]hen federal judges in New York attempt to predict uncertain Florida law, they act . . . as 'outsiders' lacking the common exposure to local law which comes from sitting in the jurisdiction." Id. at 391.

Teunessee, unlike Florida, has no statute providing for certification of state law questions to the state supreine court; thus, this option was not available to either the Sixth Circuit in Memphis Development or the Second Circuit in Factors. 
surely surpasses our own."72 Significantly, however, the Factors majority expressly declined to base its holding of deference to Memphis Development on the Sixth Circuit's expertise concerning Tennessee state law. Noting that the Sixth Circuit's opinion in Memphis Development "emphatically disclann[ed] any basis for predicting how Tennessee will resolve the issue on the merits." 73 The majority stated in a footnote that "[it] preferred to determine the authoritativeness of Memphis Development with regard to the territorial scope of the Sixth Circuit, rather than the heritage of the opinion's author."74

Fimally, the majority in Factors went to great lengths to lay the groundwork for a strict standard of deference. Although the court stopped short of concluding that determinations of unsettled state law by pertinent circuit courts are "automatically binding" on all other federal courts, ${ }^{75}$ it stated that federal courts should defer to such interpretations "in all situations except the rare instance when it can be said with conviction that the pertinent court of appeals has disregarded clear signals emanating from the state's highest court pointing toward a different rule."76

\section{B. Criticism of Factors}

The Factors court's construction of a strict standard of intercircuit deference contains four inajor flaws. First, the Factors holding of deference is based not on the pertiment circuit court's expertise concerning a particular state's law and court methods but rather on its "territorial

72. 652 F.2d at 283 n.7.

73. The Memphis Development court clearly eschewed any resort to Tennessee law, stating that "Tennessee courts have not addressed [the] issue directly or indirectly, and we bave no way to assess their predisposition." 616 F.2d at 958 . Rather, the decision denying the descendibility of the right of publicity was made "in the hight of practical and policy considerations, the treatunent of other similar rights in our legal system, the relative weight of the conflicting interests of the parties, and certain moral presuppositions concerning death, privacy, inheritability and economic opportunity." Id. In evaluating these general considerations, the Sixth Circuit relied on J. RAwLS, A Theory of Justice (1971) and the Restatement (SECOND) OF TorTs (Rev. ed. 1977). See 616 F.2d at 959 .

74. 652 F.2d at 283 n.7.

75. Id. at 283 . The court stated that "[a] federal court in another circuit would be obliged to disregard a state law holding by the pertinent court of appeals if persuaded that the holding had been superseded by a later pronouncement from state legislative or judicial sources, or that prior state court decisions had been inadvertently overlooked by the pertinent court of appeals." Id. (citation omitled).

76. Id. The Factors court also stated its standard as follows: "[W]e should defer to the views of the Sixth Circuit unless we can point to a clear basis in Tennessee law for predicting that the Tennessee courts, when confronted with a case such as this, would conclude that the Sixth Circuit's prediction was imcorrect." Id. (footnote omitted). See infra notes 101-07 and accompanying text. 
scope."77 As such, the Factors reasoning differs from the sound rationale on which federal courts of appeals have previously grounded their deference to the state law interpretations of federal district court judges on direct review. ${ }^{78}$ Faced with a Sixth Circuit decision that not only expressly declined to predict how the Supreme Court of Tennessee would have decided the case, ${ }^{79}$ but also summarily rejected the state law imterpretation of a federal district court judge, ${ }^{80}$ the Factors court could not invoke the expertise rationale to support its holding of deference. Rather than examining the merits of the state law question, the court deferred to the Memphis Development decision based upon the apparently novel and highly questionable concept of the "territorial scope" of the Sixth Circuit.

A pertinent circuit court panel's special familiarity with the law and court methods of a state located within its jurisdiction arguably renders it particularly qualified to apply the substantive state law that a state's supreme court would apply in the same situation.81 If this special familiarity is of no consequence to the pertinent court's decision, however, the inere fact that the "territorial scope" or physical bounda-

77. See supra text accompanying note 74. The court did not define what it meant by "territorial scope"; the term apparently denotes simply that the state of Tennessee is located within geographical boundaries of the Sixth Circuit.

78. The deference that higher federal courts have afforded to interpretations of state law by federal district courts is based on the district judge's familiarity with the law and legal practice of the state in which he sits. See supra notes $44-47$ and accompanying text.

79. See supra note 73. By declining to predict how the Supreme Court of Tennessee would have decided the issue, the Sixth Circuit failed to heed Erie's directive that a federal court should attempt to resolve questions of state law in the same manner as the supreme court of that state. See, e.g., Hartford v. Gibbons \& Reed Co., 617 F.2d 567, 569 (10th Cir. 1980) (construing New Mexico law as would the New Mexico Supreme Court); Scandinavian Airline Sys. v. United Aircraft Corp., 601 F.2d 425, 427 (9th Cir. 1979) (in absence of definitive adjudication by California Supreme Court, court of appeals sought to resolve issue as would the California court); Winston Corp. v. Continental Casualty Co., 508 F.2d 1298, 1304 (6th Cir.), cert. denied, 423 U.S. 914 (1975) (court decided suretyship case under Georgia law as it thought Supreme Court of Georgia would have done). See supra note 63.

80. Memphis Dev. Found. v. Factors, Inc., 616 F.2d 956 (6th Cir. 1980), rev'g 441 F. Supp. 1323 (W.D. Tenn. 1977), cert. denied, 449 U.S. 953 (1980). In his opinion holding that the right of publicity is descendible nnder Tennessee law, District Court Judge Wellford looked both to the majority rule on the issue of the descendibility of the right of publicity and to Tennessee decisions in analogous areas. 441 F. Supp. at 1330. On appeal, the Sixth Circuit apparently afforded no deference to this decision of a district judge who possessed considerable expertise in Tennessee law. It is indeed ironic that the Factors court chose to set forth its broad rule of intercircuit deference by deferring to a decision that itself ignored an already well-established rule of federal appellate court deference to district court judges' interpretations of state law. See supra notes 4447 and accompanying text.

81. See supra notes 43-52 and accompanying text. In his dissent, Judge Mansfield questioned the validity of this proposition:

Unlike a state court or a federal district court within a single state, the court of appeals of a circuit in which several states are located, which disposes of diversity appeals as only a 
ries of the circuit encompass a particular state does not render the pertinent court of appeals better able to interpret the law of that state than other courts of appeals. ${ }^{82}$ Absent the key element of expertise, the Factors court's designation of pertinent circuit court interpretations of unsettled state law as authoritative rests on no more than an arbitrary geographical distimction.

The second flaw in the Factors court's reasoning stems from the court's belief that the primary goal of federal courts ascertaining unsettled state law is to achieve absolute uniforumty in the application of state law among the federal courts, rather than to ensure that a federal court applies the same substantive rule that a state court would apply. The Factors court based its emphasis on the former kind of uniforimty on its understanding of the "functioning of diversity jurisdiction," the goal of which, according to the court, is to brimg order and consistency to the development of state substantive law..$^{83}$ The Factors court's view of the possibility that federal courts might render incorrect interpretations of state law that are not reviewable by a state court as a "price [that] must be paid . . . [a]s long as diversity jurisdiction exists" onstrates the court's disregard of the basic Erie tenet that a federal court sitting in diversity is to interpret state law as would a state court in the same situation.

In an ideal system, both intercircuit and federal-state uniformity could be achieved at once; all federal courts would agree on the correct imterpretation of a particular state law issue. When a federal court disagrees with or questions the interpretation of a pertinent circuit court, however, one kind of uniformity inust be sacrificed. By deferring to the Sixth Circuit interpretation on grounds totally unrelated to the Sixth Circuit's expertise, the Factors court clearly close to pursue intercircuit

small percentage of its business, is not likely to gain any special familiarity with the law of one of the states within its boundaries.

652 F.2d at 285 (Mansfield, J., dissenting). Cf. Note, supra note 29, at 756 ("Certainly a federal district judge may be required to deal with the law of his state more frequently than federal circuit court judges whose circuit imcludes many states, yet this fact alone does not make him more expert in the field.").

82. See 652 F.2d at 286 (Mansfield, J., dissenting).

83. Id. at 282-83. The majority stated: "Diversity jurisdiction, cspecially in its post-Erie incarnation, should not create needless diversity in the exposition of state substantive law." Id. at 283. The opinion's heavy emphasis on the "orderly" and "authoritative" exposition of state law and the rigid standard of deference which the opinion sets forth illuminate the court's apparent view that any annount of diverseness in the federal adjudication of state law is "needless." Id.

84. The majority noted:

Except in those few jurisdictions permitting a federal court to certify an unsettlcd question of state law to the state's highest court, a federal court's decision on state law cannot be corrected for the benefit of the litigants in the particular case by the state's authoritative tribunal. As long as diversity jurisdiction exists, this price must be paid. Id. at 282 . 
uniformity at the expense of federal-state uniformity, giving rise to the dissent's admonition that "[s]oundness must not be sacrificed on the altar of consistency."85

The Factors court's pursuit of consistency in federal court interpretation of state law threatens to undermine what the Supreme Court has termed the "twin aims" of the Erie doctrine: "discouragement of forum-shopping and avoidance of inequitable admimistration of the laws."86 Factors creates the same potential for forum-shopping that Field created in requiring federal judges to follow all lower state court decisions. ${ }^{87}$ For example, once a pertinent federal court of appeals decides an unsettled question of state law, a hitigant is virtually assured of achieving that same outcome in any federal court in the nation. Conversely, a litigant who seeks an outconie contrary to a pertinent circuit court decision will surely choose a state forum in which the federal court decision is not binding.

The Factors rule could also lead to inequities in the administration of state law. Under Factors, once a pertinent circuit court has rendered an interpretation of an issue of state law, a federal court may not thereafter give the same full consideration to the merits of that issue as may a state court. ${ }^{88}$ This discrepancy in the scope of authority that federal and state courts possess im evaluatimg pertinent circuit court interpretations under the Factors rule impedes the equitable administration of the law in two ways. First, litigants in federal court do not receive the benefit of the flexibility that a state court exercises in evaluating a pertinent circuit court interpretation of state law. The Court of Appeals for the Third Circuit recognized in an analogous context the impact that "mechanical" federal court deference to unauthoritative state law interpretations can have on diversity litigants:

A diversity litigant should not be drawn to the federal forum by the prospect of a more favorable outcome than lie could expect in the state courts. But neither should he be penalized for his choice of the federal court by being deprived of the flexibility that a state court could reasonably expect to show. 89

85. Id. at 286 (Mansfield, J., dissenting).

86. Hanna v. Plumer, 380 U.S. 460,468 (1965). The Court in Hanna stated that "[t]he 'outcome-determination' test [of Guaranty Trust Co. v. York, 326 U.S. 99 (1945)] . . . cannot be read without reference to the twin aims of the Erie rule: discouragement of forum-shopping and avoidance of inequitable administration of the laws." 380 U.S. at 468. Hanna's modification of the York test demonstrates the Court's view that absolute uniformity should not be an end in itself.

87. See supra notes 21-22 and accompanying text.

88. See supra note 29.

89. Becker v. Interstate Properties, 569 F.2d 1203, 1206 (3d Cir. 1978). The issue in Becker was whether an employer was liable for the tort of an independent contractor under New Jersey 
The Factors rule imposes just suclı a penalty on diversity litigants. In some cases, the penalty may consist of the federal court's application of the incorrect state law interpretation.

The Factors policy of deference also impedes the equitable administration of state law by increasing the risk that obsolete ${ }^{90}$ or incorrect determinations of state law by pertinent circuit courts will be perpetuated in the federal courts until contradicted or overruled by the state supreine court.91 Given the Factors court's view that federal court imterpretations of state law are not easily corrected by a state's highest court or legislature, ${ }^{92}$ it is ironic that the court set fortl a policy of deference that could extend the impact of an incorrect interpretation by a pertinent circuit court to all of the federal courts of appeals.

The equitable administration of state law is best achieved when a federal court considers all available data, from botll the law of a state and the law of other jurisdictions, and then predicts how the state court would have decided the issue. Such a prediction should not be a mere recitation of a prior decision that a state court would not deem controlling.93 By mandating rigid uniformity in the federal courts based on a single federal court's interpretation of state law at a given time, the Factors pohcy of deference does not advance the broader purposes of Erie, but rather undermines them.

The third drawback to the Factors rule of conclusive deference is that it will not significantly reduce the number of divergent outcomes that traditionally result froin the federal courts' interpretations of unsettled state law. Even if the arbitrary nature and inequitable effects of

law. There were no New Jersey cases on point, but there were recent dicta that brought into question the traditional doctrine of employer immunity for the acts of independent contractors. The court noted its obligation to render a prediction of what a New Jersey court would do if faced with the question: "In the course of discharging our obligation, we must clioose either to reject or to accept a nascent legal rule, and thus risk distorting state law as much by an excess of conservatisin as by insufficient attention to stare decisis." Id. at 1204. The Becker court noted that the trend in the New Jersey courts was away from employer immumity, and concluded that the New Jersey courts would have held the employer liable under a new exception. Id. at 1214.

90. Doctrinal trends in state law that occur after a pertinent federal circuit court's dccision could dictate a different outcome from that previously reached, were a state court to addrcss the issue. Under the Factors standard, however, such trends would not constitute evidence sufficient to justify a federal court's departure from the pertinent federal circuit court's intcrpretation. See supra note 76.

91. The Factors court's application of the Memphis Development court's view of the descendibility question exemplifies how under a policy of conclusive deference an essentially incorrect federal court interpretation of state law could be perpetuated within the federal courts until contradicted by an authoritative state court decision. See infra text accompanying notes 125 27.

92. See 652 F.2d at $282-83 \&$ n.6.

93. See Becker v. Interstate Properties, 569 F.2d 1203, 1206 (3d Cir. 1978). 
the Factors rule could be justified by a compelling need to attain order and consistency in federal court interpretation of state law, the Factors rule would not satisfy such a need. As Judge Mansfield observed im his dissent, whatever uniformity might be achieved in the federal courts would be "fortuitous and arbitrary"; federal courts would still be free to disregard interpretations of state law by federal courts of appeals other than the pertinent circuit, and thus "create the very inconsistency which the majority seeks to avoid." 94

The Factors majority's contention that a policy of deference to pertinent federal circuit court interpretations would proinote the "orderly development of state law" is based on several speculative and perhaps ill-founded assumptions. The majority's theory that the existence of a single, "authoritative" interpretation of unsettled state law by the pertinent court of appeals would "focus state legislative efforts on the appropriateness of a statutory change" 95 seems no more persuasive than the dissent's suggestion that a state legislature would be more likely to act in the presence of conflicting federal court interpretations. ${ }^{96}$ In addition, the Factors court made the unwarranted assumption that the uniform application of a particular state's law in the federal courts would prompt other state courts applying the same state's law to accept the federal interpretation out of a common interest in uniformity. ${ }^{97}$ Historically, state courts have tended not to follow federal court interpretations of state law; ${ }^{98}$ more often, they have looked to decisions froin neighboring states. ${ }^{99}$

94. 652 F.2d at 286 (Mansfield, J., dissenting).

95. Id. at 282. It is ironic that under the majority's theory, federal courts would need to apply an incorrect interpretation consistently in order to prompt corrective action by a state's legislature.

96. In his dissent, Judge Mansfield countered the majority's proposition as follows: "If Tennessee constituents were laboring under conflicting federal court declarations of rights and duties, the legislature would be unore likely to act sooner than if all decisions were consistent." 652 F.2d at 286.

97. Id. at 282 n.6.

98. A basic premise of the doctrine of Swift v. Tyson, 41 U.S. (16 Pet.) 1 (1842), see supra note 3, was that independeut determinations of general law by federal courts would be followed by the states, promoting uniformity in the law. History shows that this premise was faulty: the Swift doctrine was gradually narrowed until it was repudiated entirely by the Erie decision. See C. WRIGHT, supra note 1, \$ 56, at 261; see also Note, The Effect of Diversity Jurisdiction on State Litigation, 40 IND. L.J. 566, 584 (1965) (conprehensive study examining all diversity cases in Court of Appeals for the Seventh Circuit from 1938-1963 showed no state tendency to follow federal court interpretations of state law).

99. See, e.g., Yost v. Morrow, 262 F.2d $826,828 \mathrm{n} .3$ (2d Cir. 1959) (in situation in which no Idaho conflict of laws statute existed, court assumed Idaho court would look to decisions of its sister state, Oregon); Wilmingtou Trust Co. v. Mutual Life Ins. Co., 76 F. Supp. 560, 565 (D. Del. 1948) (taking legal notice that Delaware courts pay particular attention to Massachusetts court decisions). 
The clearly unpersuasive nature of the arguments set forth by the Factors majority to support its policy of intercircuit deference indicates that the real force behind the holding may have been an unspoken desire to promote judicial economy. But the Factors form of deference would fail to promote judicial economy for the same reason that it would not brimg about greater horizontal uniformity in the apphication of unsettled state law in the federal courts: the impact of the Factors rule is limited to cases in which a pertinent circuit court interprets an unsettled question of state law. 100 Under Factors such an interpretation by a federal court other than the pertinent circuit court would require no deference froin federal courts in other circuits.

In order to have a perceptible impact on the diversity workload in the federal courts, a pohicy of intercircuit deference would have to mandate deference to all circuit court interpretations of unsettled state law, not merely those of the pertinent circuit. By failing to base its holding on the rationale of a pertinent circuit court's expertise and at the same time limitimg its requirement of deference to pertinent circuit court decisions, the Factors court sacrificed the soundness of interpretation arguably imphicit in a pohicy of deference based on expertise without gaining any more than a nominal increase in either horizontal uniformity or judicial efficiency.

The fourth inajor flaw in the Factors approach is that the standard employed by the court overly restricts the extent to which the deferring court may examine relevant law. Under the Factors rule, federal courts are bound to follow an interpretation of state law by the pertinent federal circuit court unless there is a clear showing from a state supreme court decision that a state court would hold to the contrary. ${ }^{101}$ This standard, when apphed to a pertinent federal circuit court's interpretation of a state law question that has not been addressed by any state court, necessarily requires "conclusive deference." 102 For example, in Factors, there was no Teimessee law that the court could consult on the question at issue. As a result, the Second Circuit considered itself bound by the Sixth Circuit's interpretation even though there was evidence outside- of Termessee law, including the reversed federal district

100. See supra text accompanying note 94 .

101. See supra note 76 and accompanying text. .

102. Professor Wright's criticism of the "conclusive deference" that some federal courts have afforded lower state court decisions seems equally valid in the Factors context: "It would seem that a party is entitled to review the trial court's determination of state law just as he is of any other legal question in the case, and that the decision of the local trial judge cannot reasonably be regarded as conclusive." C. WRIGHT, supra note 1, § 58, at 271. 
court decision, that the Sixth Circuit may have decided the issue incorrectly. ${ }^{103}$

The Factors standard is thus stricter than the "clearly erroneous" standard that some federal courts of appeals employ when reviewing district court interpretations of state law, 104 and far more inflexible than the "great weight"10s standard that most courts and commentators have favored. 106 Commentators have criticized the "clearly erroneous" standard as "treating the question of state law much as if it were a question of fact."107 The same objection applies to the Factors standard, which requires a firm conviction that the pertinent circuit court has disregarded a clear indication from a state supreme court decision supporting a contrary interpretation. ${ }^{108}$

The Factors standard of deference is especially liarsh because it requires deference not to a district judge's state law interpretation on appeal, but rather to a decision rendered in a completely different law-

103. There is ample case law and commentary supporting the proposition that the right of publicity is descendible. See, e.g., Factors, Etc., Inc. v. Pro Arts, Inc., 579 F.2d 215 (2d Cir. 1978), cert. denied, 440 U.S. 908 (1979) ("Factors I"); Estate of Presley v. Russen, 513 F. Supp. 1339 (D.N.J. 1981); Hicks v. Casablanca Records, 464 F. Supp. 426 (S.D.N.Y. 1978); Factors, Etc., Inc. v. Creative Card Co., 444 F. Supp. 279 (S.D.N.Y. 1977); Price v. Hal Roach Studies, Inc., 400 F. Supp. 836 (S.D.N.Y. 1975); see also Felcher \& Rubin, The Descendibility of the Right of Publicity: Is There Commercial Life After Death?, 89 YALE L.J. 1125 (1980).

104. See supra note 47 and accompanying text. Whereas a federal court of appeals' application of the "clearly erroneous" standard jcopardizes the right of diversity litigants to have a federal district court's interpretation of state law fully reviewed on appeal, the Factors standard of intercircuit deference would preclude litigants from receiving full consideration of their claims at any stage of the action.

105. See supra note 46 and accompanying text.

106. See J. MOORE, supra note 21, I 0.309 [2], at 3125 .

107. See C. WrIGHT, supra note $1, \S 58$, at 271 . There is indeed a danger in using the same standard of review for a federal district court's interpretation of state law as is used for a finding of fact. The fact-finding function has traditionally been within the province of the trial court. Consequently, such findings are accepted on review unless found to be clearly erroneous. The function of interpreting law, on the other hand, is one that is not appropriately conducted by any single court. To be sure, soine judges possess characteristics that inay render thein better suited than others to make certain kinds of legal determinations; it is for this reason that rules of deference exist. But the difference in various judges' ability to interpret the law is one of degree rather than kind; thus, a standard of review as preclusive as the "clearly erroneous" standard is not appropriate for findings of law. One commentator's criticism of the Field Court's apparent reliance on Erie to support its rule of strict deference to lower state court decisious also seem relevant in light of Faciors:

[T] he very essence of the Erie doctrine is that a federal judge can find, if not make, the law almost as well as a state judge. Certainly, if the law is not a brooding omnipresence in the sky over the United States, neither is it a brooding ommipresence in the sky of Vermout, or New York or California. The bases of state law are assuuned to be communicable by lawyers to judges, federal judges no less than state judges.

Kurland, supra note 16, at 217.

108. See supra note 76 and acconipanying text. When there is no state law on the question at issue, a federal court nust follow a pertinent circuit court's interpretation even when all data outside state law indicate that the pertinent circuit court lolding is incorrect. 
suit by a federal court in another circuit. Indeed, such deference could foreclose the rights of litigants who were not parties to the original case. The binding nature of pertinent circuit court decisions would thus extend beyond that of the doctrine of stare decisis, under which courts are generally free to overrule a prior decision if it is obsolete or incorrect, ${ }^{109}$ and would in effect carry the force of res judicata.

\section{- III. A Proposal for Reasoned Deference}

The factual situation in Factors was clearly not conducive to the Second Circuit's articulation of a policy of deference among federal courts of appeals. The Sixth Circuit's express disregard of Tennessee law in Memphis Development, ${ }^{110}$ coupled with its reversal of the federal district judge's decision, ${ }^{111}$ prevented the Factors court from making use of the most compelling rationale for a policy of deference-that of expertness. ${ }^{112}$ The Factors court added to its probleins by seeking to achieve uniformity of state law among the federal courts at the expense of broader Erie concerns, ${ }^{113}$ and by constructing an inflexible standard of deference. ${ }^{114}$

Despite the weaknesses in the Factors decision, the basic concept of establishing some degree of formal deference among federal courts sitting in diversity does merit consideration. The Factors court was not mistaken in its observation that some "needless diversity" exists in the exposition of state law. ${ }^{115}$ The court merely erred in its apparent belief that all such diverseness is unnecessary and must be eliminated, regardless of cost. ${ }^{116}$ The federal system of diversity jurisdiction could benefit from a rule of reasoned deference that would both promote federalstate uniformity of state law and frequently produce the desirable side effect of uniformity of state law among the federal courts. ${ }^{117}$ A worka-

109. Professor Moore states that under the doctrine of stare decisis a prior federal court of appeals decision is generally regarded as "persuasive" in a subsequent case in the same circuit. See J. MooRE, supra note 21, \$ 0.309[2], at 3125. Moore also notes, however, that in some circuits, such as the Fifth Circuit, such decisions are controlling unless the court overturns the decision sitting en banc. Id. \& n.25.

110. See supra text accompanying notes $62-63$ and note 73 .

111. See supra note 80 and accompanying text.

112. See supra notes $78-82$ and accompanying text.

113. See supra notes $86-93$ and accompanying text.

114. See supra notes 101-09 and accompanying text.

115. See supra notes $83-84$ and accompanying text.

116. For a discussion of the problems inherent in a pohicy mandating rigid adherence to state law interpretations of courts other than the state supreme court, see supra text accompanymg notes 21-29 and 78-109.

117. A formal policy of deference to pertinent circuit court interpretations of unsettled state law would be especially helpful in high of the fact that many states do not have statutes allowing federal courts to certify undecided questions of state law to the state's highest court. 
ble policy of intercircuit deference must differ froin the Factors policy, however, in at least two respects. First, a sound rule of deference must be grounded on considerations of expertness and of proper inquiry into state law and state court methods. ${ }^{118}$ To merit deference, a pertiment circuit court's holding must have been based on a well-reasoned prediction, rendered by either the pertinent circuit or the federal district judge below, of how a state court would have decided the issue. ${ }^{119}$

Certification procedures are provided for by statute or court rules in several states, including Colorado, Florida, Louisiana, Maine, Maryland, Massachusetts, Minnesota, Montana, New Hampshire, Oklahoma, and Washington. See, e.g., Colo. App. R. 21.1 (1973); Fla. Stat. ANN. $\$ 25.031$ (West 1974); LA. Sup. CT. R. 12 (West Supp. 1982); Me Rev. Stat. ANN. tit. 4, § 57 (1979); MD. CTS. \& JuD. PROC. § 12-601 (1980); Mass. Sup. Jud. CT. R. 1:03 (1981); MinN. STAT. ANN. § 480.061 (West Supp. 1982); MoNT. Sup. CT. R. 1 (1973); N.H. Rev. STAT. ANN. § 480.061 (West Supp. 1982); OKLA. STAT. ANN. tit. 20, $\$$ 1601-1612 (West. Supp. 1982); WASH. REv. CodE ANN. \& 2.60 (West Supp. 1982). The Supreine Court endorsed the certification procedure in Lehman Bros. v. Schein, 416 U.S. 386 (1974), noting that "in the long run [it saves] time, energy, and resources and helps build a cooperative judicial federalisın." Id. at 391 (footnote omitted). Many commentators have enthusiastically supported the certification procedure. See, e.g., Kurland, Toward a Co-operative Judicial Federalism: The Federal Court Abstention Doctrine, 24 F.R.D. 481 (1960); Lillich \& Mundy, Federal Court Cerification of Doubtful State Law Questions, 18 U.C.L.A. L. Rev. 888 (1971); McKusick, Certification: A Procedure for Cooperation Between State and Federal Courts, 16 ME. L. REv. 33 (1964). Other commentators, however, point out that the expense and delay caused by the procedure, as well as its inherently "advisory" nature, may make it an undesirable innovation. See, e.g., C. WRIGHT, supra note 1, \$ 52, at 226-27; Cardozo, Choosing and Declaring State Law: Deference to State Courts Versus Federal Responsibility, 55 Nw. U. L. Rev. 519 (1960); Mattis, Certification of Questions of State Law: An Impractical Tool in the Hands of the Federal Courts, 23 U. MIAMI L. REv. 717 (1969).

Because federal court certification of unsettled state law questions to state supreme courts is not mandatory and may cause considerable delay, federal courts may in some cases choose to defer to a well-reasoned interpretation of the issue by a pertinent circuit, even when a certification procedure is available. Thus, the existence of certification procedures does not eliminate the need for a policy of deference among the federal courts.

118. In Becker v. Interstate Properties, 569 F.2d 1203 (3d Cir. 1977), the Third Circuit declined to defer to an interpretation of Delaware law by a district judge who had based his ruling on factors outside of state law. The court stated:

We have taken serious notice of the determination by the trial court that New Jersey

would not adopt the position which we set forth. Judge Fisher's views, of course as a

member of the New Jersey bar with long experience are entitled to great weight. None-

theless, since his analysis rested solely on general policy and out-of-state cases, we do not

believe the trial judge's views bind us.

Id. at 1206 n.8.

Had the district judge in Becker based his interpretation of Delaware state law on considerations within the realm of his particular expertise, the Third Circuit probably would not have felt as free to differ with the initial imterpretation. Unlike the Becker court, the Factors court expressed no concern that the Sixth Circuit's holding in Memphis Development did not merit deference because it was based entirely on considerations of general policy and not state law.

119. Most courts now employ such a prediction procedure in deciding issues of unsettled state law. The Third Circuit has identified the following sources to be used in predicting the course of state law: decisions by the state's highest court in analogous cases; considered dicta of the state supreme court; decisions by lower state courts and other federal courts, which should be afforded "proper regard" but not conclusive effect; and any other reliable data indicating low the state's highest court would decide the issue at hand. See, e.g., Safeco Ins. Co. of Am. v. Wetherill, 
Second, a rule of reasoned deference must permit federal courts to reject pertinent circuit court interpretations that are obsolete or incorrect. ${ }^{120}$ The Factors decision itself demonstrates that neither the purposes of the Erie doctrime nor the function of diversity jurisdiction is served by a system that allows a federal court to decide novel questions of state law on grounds entirely independent of state law, and also binds all other federal courts to follow that interpretation unless they can clearly show froin state law that it is incorrect.

In practical terms, a flexible rule of.deference might require a federal court first to make a threshold determination whether the pertinent circuit court did inake an inquiry into state law or state court procedure in an attempt to predict how a state court would have decided the question If-no such inquiry was inade, the federal court should not defer to the pertinent circuit court's decision. ${ }^{121}$ If the pertinent circuit court

622 F.2d 685, 688 (3d Cir. 1980); McKenna v. Ortho Pharmaceutical Corp., 622 F.2d 657, 661 (3d Cir.), cert. denied, 449 U.S. 976 (1980). In short, a federal court's prediction should be the result of an inquiry into sources to which a state court would normally turn for guidance on questions of first impression. Although this method does not eliminate the possibility that federal courts will make erroneous interpretations, it is more likely to produce the result that a state court would reach, and thus promote Erie uniformity, than would interpretations based on a federal judge's imdependent judgment or on a mechanical application of unauthoritative existing law. See Note, Federal Interpretation of State Law-An Argument for Expanded Scope of Inquiry, 53 MinN. L. REv. 806, 816-17 (1969).

120. In Safeco Ins. Co. of Am. v. Wetherill, 622 F.2d 685 (3d Cir. 1980), the court declined to defer to an intermediate state court decision that it believed was incorrectly decided, stating that it was "not obhiged to give any such source more precedential value than would be given to it by the state's highest court." Id. at 688. The court explained that

while a decision of Pennsylvania's intermediate appellate court would be entitled to

"some weight", it is diffcult to accord the . . . decision such weight because it provides

us with no analysis. Furthermore, it cites as support three Pennsylvania decisions whicl

we are unable to read as, in fact, supportive of the result.

Id. at 689 (citations onnitted).

In McKenna v. Ortho Pharmaceutical Corp., 622 F.2d 657 (3d Cir.), cert. denied, 449 U.S. 976 (1980), the Third Circuit declined to follow an analogous nine-year-old state supreme court decision that had never been expressly overnuled but whose authoritativeness on the question at issue was arguable. The court stated that although analogous decisions by a state supreme court provide useful indications of that court's probable disposition of a question of unsettled state law, a federal court's prediction could not be the product of a inere recitation of previously decided cases. The court noted that federal courts should not give state court decisions more bimding effect than would a state court under the same circumstances. "Rather, relevant state precedents must be scrutinized with an eye toward the broad policies that informed those adjudications, and to the doctrinal trends which they evince." Id. at 662 .

It would hardly make sense if federal courts were free to disregard lower state court decisions that they deeined obsolete or imcorrect - n gronnds that such decisions would not be binding on a state court in the same circumstances-but at the same time were bound to defer to pertinent federal circuit court decisions that would not be binding on a state court. Federal courts slould adopt the same approach in reviewing pertinent circuit or district court decisions as they have employed when evaluating lower state court decisions or federal district court interpretations of state law on appeal, naniely, one of reasoned deference and not blind adlierence.

121. See supra note 118. 
made a reasonable effort to inquire into state law, or deferred to a wellgrounded prediction by a federal district court judge, a federal court should then give "great weight" to the holding. ${ }^{122}$ Under this standard of deference, a federal court would regard an adequately grounded pertinent circuit court interpretation of state law as highly persuasive, and would defer to the holding unless convinced that the pertinent circuit had erred. 123

In addition, unlike the Factors rule, the proposed policy of deference would permit a federal court to examine the same breadth of data that the pertinent circuit court consulted in rendering its interpretation. This is not to say that federal courts should engage in a detailed review of all of the pertinent circuit court's conclusions. To the extent that a pertinent circuit court is free to render a prediction based on sources outside a state's law, however, other federal courts nust be allowed a scope of review sufficiently broad to permit disagreement with that prediction when it is clearly ill-founded. ${ }^{124}$

A rule of deference considerably more flexible than that of Factors would be desirable for several reasons. First, such a rule would avoid perpetuating obsolete or incorrect interpretations of state law within the federal court system. Significantly, the Sixth Circuit's decision in Memphis Development has recently been contradicted by a Tennessee chancery court holding ${ }^{125}$ and thus may not warrant deference even

122. Because the proposed rule of deference is grounded on considerations of expertise, unappealed decisions by district judges would merit a comparable degree of deference.

123. Review of a pertinent circuit court's interpretation by a federal court subsequently faced with the same issue would thus be a two-step procedure. The first step would be to examine the methods by which the pertinent circuit court had reached its decision and to determine whether some amount of deference should be afforded the interpretation. The second step, if needed, would be to evaluate the merits of the pertinent circuit court's decision under the "great weight" standard of deference.

Conceivably, the amount of weight given a pertinent circuit court decision might vary according to factors such as whether the court of appeals' opmion reversed or affirmed the district judge's interpretation and whether the state law issue decided was one uniquely local in nature or involved a more common subject area such as the Uniform Commercial Code, with which most federal judges are familiar. For example, pertinent circuit court decisions that reverse interpretations of state law by district court judges, as did the Sixth Circuit's decision in Memphis Development, would be afforded hittle or no deference. At the same time, when both a federal district judge and the pertinent court of appeals render the same prediction of state law, such an interpretation is likely to be accurate and would be afforded substantial deference. This distimction is consistent with the notion that expertise is at the root of the rule of deference.

124. A broad scope of review is imperative for obvious reasons. Cases that turn on state law questions on which there is no existing state law, such as Factors, necessarily oblige a federal court to look to sources outside state law. Review of such decisions is rendered virtually meaningless when other federal courts may evaluate the pertinent circuit's interpretation based only on factors within state law.

125. A Tennessee chancery court judge recently considered the issue of whether an entertainer's right of publicity is descendible, and reached a result directly contrary to that of the Sixth 


\section{within the Sixth and Second Circuits. ${ }^{126}$ Ordinarily, however, state courts cannot be expectcd to rectify ill-founded interpretations of state}

Circuit in Memphis Development and the Second Circuit in Factors. See Commerce Union Bank v. Coors, Media L. Rep. (BNA) 2204 (Tenn. Ch.). Citing two analogous state court decisions on which the federal district judge had rehed in Memphis Development, decisions in other jurisdictions, and Judge Mansfield's dissent in Factors, the chancery court judge held that the right of publicity is descendible under Teunessee law. The chancery court opimion, rendered on a motion to dismiss, expressly contradicted the Sixth Circuit's holding in Memphis Development:

The Sixth Circuit's opinion in Memphis Development is irreconcilable with this Court's decision that the right of publicity is descendible and the majority view on this issue. Understandably, the defendant emphasises, [the Sixth Circuit's opmion], an empliasis not misplaced simce the Sixth Circuit was attempting to apply Tennessee law. Of course, that federal court decision is not binding on this Court, just as the district court's decision in the same case whicl held the opposite is not binding. This Court, however, finds the reasoning of the district court more persuasive than that of the appellate court. Id. at 2207.

Had the court in Factors followed the Erie directive and predicted how a state court would decide the issue instead of blindly following the Sixth Circuit's interpretation, it inight also have reached the conclusion that the district judge's reasoning was more persuasive than that of the circuit court.

The chancery court opimion quoted extensively from the portions of Judge Mansfield's dissent in Factors that pointed out that the Sixth Circuit's opinion in Memphis Development was in no way derived from Tennessee law. In addition, the chancery court judge dismissed the Second Circuit's decision in Factors as follows: "The Second Circuit followed the Sixtli Circuit not because it agreed with the holding on the inerits, but because it felt that it was bound to do so because Tennessee is within the Sixth Circuit." Id. at 2207-08. Fimally, the court noted that the right of publicity should be descendible not only because judicial precedent and considerations of fundamental fairness and property interest support descendibility, but also because public policy dictates that the efforts and energies of Tennessee artists be protected. Id. at 2208 (citing Factors, 652 F.2d at 288 (Mansfield, J., dissenting)).

126. Although it is questionable whether federal or state courts outside the Sixth and Second Circuits would have deferred to the interpretation of the court in Memphis Development, courts will now be even less likely to follow Memphis Development without first making an independent determination of the issue on the merits. Technically, the decision in Memphis Development could remain "good law" nntil the Supreme Court of Tennessee renders a contrary interpretation. The chancery court's opinion in Commerce Union Bank v. Coors clearly casts doubt on the validity of the Sixth Circuit's decision in Memphis Development, however, particularly because the reasoning of the cliancery court opinion is inuch more developed than is the rationale in Memphis Development. It has not yet been determined whether the Factors court's holding regarding the descendibility of the right of publicity under Tennessee law remains valid after the Commerce Union Bank decision. See supra note 53. In his opinion staying entry of judgment in Factors Federal District Court Judge Tenney stated that under Vandenbark v. Owens-Illinois Glass Co., 311 U.S. 538, 543 (1941), "[a] federal court sitting in diversity has a duty to apply a new rule of state law that relates to an action sub judice." 541 F. Supp. 231, 234 (S.D.N.Y. 1982).

Regardless of the outcome of the descendibility question in Factors, the defercnce aspect of the holding will apparently continue to carry force within the Second Circuit, and was recently followed in a decision by the federal district court for the Southern District of New York. In Alcan Aluminum Ltd. v. Franchise Tax Bd. of Cal, 539 F. Supp. 512 (S.D.N.Y. 1982), the court cited Factors in deferring to a decision of the Court of Appeals for the Ninth Circuit on a question of first impression under California law. In Alcan Aluminum, a foreign parent corporation sued the California Franchise Tax Board, challenging the Tax Board's inclusion of income from foreign corporations in its calculation of unitary income tax. The Tax Board argued that the plaintiff's action in federal court was barred by the federal Anti-Injunction Statute, 28 U.S.C. § 1341 (1976), because a remedy was available to the plaintiffs domestic taxpaying subsidiary in California court. 
law by federal courts. As the majority in Factors noted, there may be "an extended period" before the state supreme court addresses the identical issue. ${ }^{127}$ Nor can the United States Suprente Court be relied on to correct a pertinent circuit court holding because it has repeatedly signaled a reluctance to review lower federal court interpretations of state law. ${ }^{128}$ Fimally, state legislatures are often neither well-suited nor inclined to fill gaps in the law left by the judiciary.

A second factor that favors a more flexible rule of deference is that such a rule would not overly restrict federal judges in ascertaining unsettled state law. ${ }^{129}$ Presumably, the role played by federal judges sitting in diversity would be no less diminished by the Factors requirement of rigid adherence to the state law interpretations of other courts of appeals than it was by the Field decision's call for a mechanical application of intermediate state court decisions. ${ }^{130}$ It indeed would be an iromic result if the federal courts, after gradually regaining the

The court rejected the defendant's contention and granted jurisdiction, deferring to the Ninth Circuit's decision in Capital Industries-EML, Inc., v. Bennett, 681 F.2d 1107 (9th Cir.), cert. denied, 102 S.Ct. 1438 (1982), that section 1341 of the statute did not bar such a claim in federal court because the interests of the parent and subsidiary were not necessarily identical. Significantly, the Alcan Aluminum court deferred to the Ninth Circuit determination despite its own doubts that "the parent and subsidiary's interests [were] not so similar that the subsidiary's action [in California court] would determine the claims of both parties. . . " 539 F. Supp. at 514-15. The court stated that "[a]s California is in the Ninth Circuit, that Court is in a better position to decide this issue of state law. ..." Id at 515 .

127. See 652 F.2d at $282-83 \&$ n.6.

128. See Bishop v. Wood, 426 U.S. $341,346-47$ \& n.10 (1976). In Bishop the Court held that a district court's "tenable" interpretation of a state statute, upheld by a divided court of appeals, was sufficient to foreclose the Court's independent examination of the state law issue. The Court stated that it had in the past "accepted the interpretation of state law in which the District Court and the Court of Appeals have concurred even if an examination of the state-law issue without such guidance might have justified a different conclusion." Id. at 346 (footnote omitted); see also United States v. Durham Lumber Co., 363 U.S. 522, 526-27 (1960); Propper v. Clark, 337 U.S. 472, 486-87 (1949); MacGregor v. State Mut. Life Assurance Co., 315 U.S. 280, 281 (1942). One commentator observed: "The real reason for the Supreme Court to bow, and it usually does, to the decisions on state law of the lower federal courts rests not on the premise of expertness but on one of econoiny of judicial administration." Kurland, supra note 16, at 217. See also Note, supra note 29, at 756 ("By leaving the final responsibility for ascertaining state law to the lower federal courts, the Supreme Court is, pro tanto, in a better position to adjudicate those great issues of government which by their very nature require its consideration.").

129. See supra notes $28-29$ and accompanying text.

130. It could be argued that federal judges would be less offended by a rule that required rigid deference to the decisions of fellow federal judges, particularly because each federal court of appeals would take comfort in knowing that its decisions on unsettled questions of the law of states within its circuit would be binding on all other federal courts. Such knowlege, however, would not allay federal judges' concern that they might be forced to "abdicate [their] judicial functions," when faced with questions of unsettled state law that had been interpreted by other pertinent courts of appeals. See supra note 28 and accompanying text. 
authority to exercise some discretion in interpreting unsettled state law, voluntarily reverted to a new form of "mechanical jurisprudence" by adopting the rule set forth in Factors.

A third consideration in support of a more measured rule of deference is the unprecedented nature of the proposition that a federal circuit court should regard a decision from another circuit as binding. Federal court deference to imterpretations of state law by other federal courts has heretofore been applied only vertically, with courts of appeals deferring to district courts within a given circuit. ${ }^{131}$ The notion that such a policy could also be employed horizontally, among the courts of different circuits, involves the additional concern of circuit court autonoiny ${ }^{132}$ and thus should be proposed with considerably more care and moderation than was exercised by the court in Factors.

A fourth reason that commends a more flexible policy of deference is that such a policy would better enable a federal court evaluating a prior interpretation of state law to simulate the procedural posture of a state court. A state court is not bound by a pertinent circuit court's holding on an issue of its own state law, and is not prohibited from considering sources outside of state law in evaluating such a holding. ${ }^{133}$ The proposed rule of deference, unlike the Factors rule, would allow a federal court evaluating a pertment circuit court decision to exercise the same flexibility as would a state court, thereby increasing the likelihood that the correct state substantive law would be applied. ${ }^{134}$

In sum, the fundamental advantage of a rule of reasoned deference is that it would both provide the federal court litigant with the benefit of the same expertise-to the extent that it exists in the pertinent circuit court-that he would receive were he before a state court, and preserve for the litigant the right to have his claim considered as fully as it would have been im a state court. One policy that a flexible rule of

131. See supra notes $44-47$ and accompanying text.

132. Aside from the Eighth Circuit's attempt to promote uniformity of federal law by deferring to the decisions of other courts of appeals, the federal courts of appeals have generally shown little willingness to follow the decisions of their sister circuits, even on matters of first impression. See supra notes $48-52$ and accompanying text.

133. This principle was demonstrated in the recent Tennessee chancery court holding in Cominerce Union Bank v. Coors, 7 Media L. Rep. (BNA) 2204 (Tenn. Ch. 1981). In Commerce Union Bank the chancery court judge contradicted the Sixth Circuit's interpretation of the descendibility question under Tennessee law, siding instead with the position adopted by federal district courts in New York and New Jersey. Although the Factors majority acknowledged in a footnote that no state court would be bound by a pertinent circuit court interprctation of state law, the Second Circuit's interpretation of the Erie doctrine as allowing the Sixth Circuit to authoritatively "declare the law of Teunessee," see 652 F.2d at 281, would give pertinent circuit court decisions a force exceeded only by a state supreme court ruling.

134. See supra notes $88-93$ \& $101-09$ and accompanying text. 
deference would not facilitate is that of judicial economy within the federal courts. A rule of reasoned deference might require a considerable expenditure of time and effort by the federal judge, ${ }^{135}$ especially because the "prediction method" of ascertaining unsettled state law has become more prevalent in the federal courts. ${ }^{136}$ But given that the Factors standard of deference would ultimately thwart the policies underlying Erie ${ }^{137}$ while only nouninally promoting judicial economy ${ }^{138}$ and that the only alternative-no deference at all-consumes at least as much judicial time and energy without providing the benefit of pertinent district and circuit court expertise, a policy of reasoned deference is certainly worth pursuing.

\section{Conclusion}

Despite the impact of Erie and its progeny, a federal court's task of ascertaining unsettled state law in diversity cases is no easier today than it was a half century ago. Depending on whether a federal court chooses to decide an unsettled question of state law by deferring to a prior interpretation by another federal court or by rendering its own prediction of how a state court would decide the issue, it will often be accused of either abdicating its judicial function at the expense of diversity litigants or thwarting uniformity of state law.

The Supreme Court's attempt forty years ago in Field to proinote uniformity of state law by requiring federal courts to defer to virtually all lower state court decisions produced inequitable results in federal diversity cases. ${ }^{139}$ As a result, the Supreme Court has since adopted an

135. One commentator has argued that the federal interest in administrative efficiency inerits due regard under the Erie doctrine, and thus might be relevant in determining how extensively a federal judge must examine the state judicial process. See Note, supra note 119, at 825 . This argument stems from the Supreme Court's decisions in Hanna v. Plumer, 380 U.S. 460 (1965), and Byrd v. Blue Ridge Rural Elec. Coop., Inc., 356 U.S. 525 (1958), in which the Court faced the separate issue of whether a state rule of law was substantive or procedural.

136. See supra notes 121-24 for a discussion of the process of first determining whether a pertinent circuit court has made a reasonable effort to predict how a state court would decide the issue and then evaluating the prediction itself. There is little doubt that the prediction procedure consumes more judicial resources than does an independent judgment rendered by a federal court. See Note, supra note 117, at 820; see also Wright, The Federal Courts and the Nature and Quality of the State Law, 13 WAYNE L. REv. 317, 322 (1967) ("[T]t is easier to make good law than successfully to predict how it will be made.").

Were a federal court to evaluate a pertinent circuit court's prediction, it would probably expend less time than if it were to render a prediction itself, but more time than would be required under the Factors rule.

137. See supra notes 86-93 and accompanying text.

138. See supra text following note 99.

139. See supra notes $28-29$ and accompanying text. 
approach that allows federal courts greater scope to interpret undecided questions of state law. 140

The Second Circuit attempted to establish a formal policy of deference among circuit courts in Factors, but was unsuccessful for several reasons. The Factors court, constrained by the facts of the case before it, was forced to base its holding that pertinent circuit court interpretations of unclear state law are generally conclusive on an arbitrary geographical distinction rather than on the premise of expertness. ${ }^{141}$ In addition, the rigid standard of deference set forth in Factors mandates, rather than encourages, adherence to pertinent circuit court interpretations, thereby leaving other federal courts virtually no authority to differ with obsolete or questionable holdings. ${ }^{142}$ Perhaps most important, the Factors decision pursues the goal of uniformity of state law among the federal courts of appeals at the expense of federal-state uniformity, ignorimg the broader Erie objectives of deterring forum-shopping and encouraging the equitable administration of the law. ${ }^{143}$ In short, the Factors rule of deference is in reality one of blind adherence: arbitrary, unbending, and potentially inequitable. As such, it will fare no better in the 1980s than did the Field rule forty years before.

Federal courts would be wise to consider adopting a rule of deference that is based on the special knowledge that federal courts throughout the nation possess with respect to the laws of particular states. Such a rule would enable federal judges to benefit from the expertise of their colleagues in other circuits while preserving their authority to disregard aberrant or obsolete interpretations of state law by other federal judges. A inore ineasured rule of deference might even succeed where Factors failed, striking a balance between the conflicting forces of equity and uniformity in the federal courts' ascertainment of state law.

Craig A. Hoover

140. See supra notes $30-41$ and accompanying text.

141. See supra notes $78-82$ and accompanying text.

142. See supra notes 101-09 and accompanying text.

143. See supra notes $86-93$ and accompanying text. 